\title{
Two Species of the Genus Melita (Crustacea : Amphipoda) from Brackish Waters in Japan
}

$\operatorname{AUTHOR}(S)$ :

Yamato, Shigeyuki

\section{CITATION:}

Yamato, Shigeyuki. Two Species of the Genus Melita (Crustacea: Amphipoda) from Brackish Waters in Japan. PUBLICATIONS OF THE SETO MARINE BIOLOGICAL LABORATORY 1988, 33(1-3): 79-95

\section{ISSUE DATE:}

1988-08-20

URL:

http://hdl.handle.net/2433/176148

RIGHT: 


\title{
Two Species of the Genus Melita (Crustacea: Amphipoda) from Brackish Waters in Japan ${ }^{1)}$
}

\author{
By \\ Shigeyuki Yamato \\ Mukaishima Marine Biological Station, Faculty of Science, \\ Hiroshima University, Onomichi P.O., Hiroshima 722, Japan
}

With Text-figures $1-12$ and Table 1

\begin{abstract}
Two species of the genus Melita, Melita setiflagella n. sp. and Melita shimizui (Uéno, 1940), are described from brackish waters in Japan. The former species is distinct in bearing the markedly setose flagellum of antenna 2. The latter has not so far been known from the Japanese waters, and shows variations in some characters, which distinguish the Japanese materials into three morphological "forms". Both species are also discernible from the other species of the genus Melita by the shape of male gnathopod 1 and female coxa 6.
\end{abstract}

The present paper is the second of the series treating the Japanese melitid amphipods. The previous report dealt with four intertidal species (Yamato, 1987), and this deals with two species from brackish waters, a new species and Melita shimizui (Uéno, 1940a). Both species are very common in estuaries in Japan and often occur sympatrically. Melita shimizui was originally described as Crangonyx shimizui from two springs on the Liaotung Peninsula of the northeast China (Uéno, 1940a, b). Later, Karaman (1981) moved this species to Melita, based upon Uéno's description. This is the first record of this species from Japan.

Materials used in this report were obtained from the following localities (Fig. 1). Fujii-gawa $\left(34^{\circ} 26^{\prime} \mathrm{N}, 133^{\circ} 15^{\prime} \mathrm{E}\right)$ : the mouth of the Fujii-gawa River, Onomichi. Nuta-gawa $\left(34^{\circ} 23^{\prime} \mathrm{N}, 133^{\circ}\right.$ $\left.02^{\prime} \mathbf{E}\right)$ : around Shinkura-bashi Bridge of the Nuta-gawa River, Mihara. Ohta-gawa $\left(34^{\circ} 24^{\prime} \mathrm{N}, 132^{\circ}\right.$ $\left.21^{\prime} \mathrm{E}\right)$ : around Yamate-bashi Bridge of the Ohta-gawa River, Hiroshima. Ochiai-gawa $\left(34^{\circ} 19^{\prime} \mathrm{N}\right.$, $\left.135^{\circ} 08^{\prime} \mathrm{E}\right)$ : the mouth of the Ochiai-gawa River, near Osaka Prefectural Fisheries Experimental Station, Misaki, Osaka Prefecture, collected by Mr. H. Ariyama. Sozu-gawa $\left(32^{\circ} 57^{\prime} \mathrm{N}, 132^{\circ} 33^{\prime} \mathrm{E}\right)$ : the mouth of the Sozu-gawa River, Mishou, Ehime Prefecture. Shioiri-hama $\left(32^{\circ} 32^{\prime} \mathrm{N}, 130^{\circ} 02^{\prime} \mathrm{E}\right)$ : Shioiri-hama estuary, near the Amakusa Marine Biological Laboratory, collected by Mr. S. Nishihama and Dr. C. Aryuthaka. Nakijin $\left(26^{\circ} 42^{\prime} \mathrm{N}, 127^{\circ} 57^{\prime} \mathrm{E}\right)$ : a concrete ditch poured from a freshwater spring, Shoshi, Nakijin, the Island of Okinawa, collected by Dr. N. Broodbakker. Hinuma $\left(36^{\circ} 17^{\prime} \mathrm{N}\right.$, $\left.140^{\circ} 29^{\prime} \mathrm{E}\right)$ : Lake Hinuma, Ibaraki Prefecture, collected by Dr. H. Morino. Gamo $\left(38^{\circ} 15^{\prime} \mathrm{N}, 141^{\circ}\right.$ $\left.00^{\prime} \mathbf{E}\right)$ : Gamo estuary, Miyagi Prefecture, collected by Mr. M. Kyouno.

The figures of each appendage are depicted from two specimens, which are the holotype and the allotype, or one male and female; the figures from subsidiary specimens are denoted by the numerals within parentheses. Specimens used for figures are numbered, like male (1). Type specimens will be deposited in the National Science Museum, Tokyo, after the study is accomplished.

1) Contribution from the Mukaishima Marine Biological Station, No. 288.

Publ. Seto Mar. Biol. Lab., 33(1/3), 79-95, $1988 . \quad$ (Article 4) 


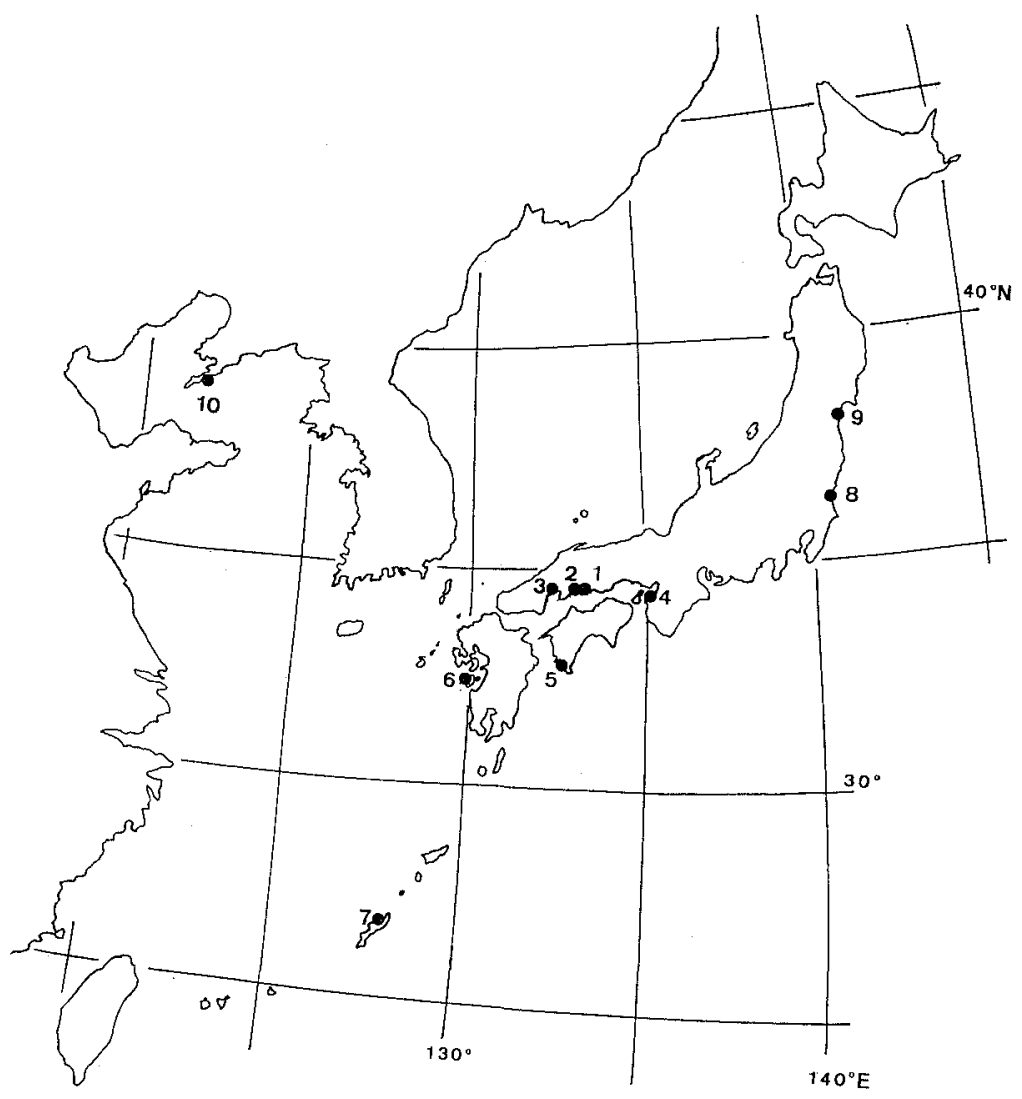

Fig. 1. Map showing the localities where materials were collected. 1, Fujii-gawa; 2, Nuta-gawa; 3, Ohta-gawa; 4, Ochiai-gawa; 5, Sozu-gawa; 6, Shioirihama; 7, Nakijin; 8, Hinuma; 9, Gamo; 10, the type locality of Melita shimizui.

Abbreviations used in the figures. R., right; L., left; A, antenna; CS, coupling spines of pleopod; CX, coxa; E, epimeral plate; G, gnathopod; IP, inner plate; LL, lower lip; MD, mandible; MX, maxilla; MXP, maxilliped; OP, outer plate; OS, oostegite; PA, palp; PL, pleopod; PLS, pleosomite; PR, pereopod; T, telson; U, uropod; UL, upper lip; URS, urosomite; f, female.

\section{Melita setiflagella n. sp.}

(Figs 2-6)

\section{(Japanese name: higetsunomerita yokoebi, new)}

Material examined. Holotype: male (1), $7.8 \mathrm{~mm}$, paratypes: allotype, female (1), $5.4 \mathrm{~mm}$, (ovigerous), 5 males and 5 females, 18 Apr. 1984, from Fujii-gawa. Male (2), $6.7 \mathrm{~mm}, 15$ Jul. 1984, from the same locality as above. Male (3), $8.4 \mathrm{~mm}, 24$ Mar. 1985, from Shioiri-hama. In addition to the above localities, a few specimens from Nuta-gawa, Ohta-gawa, Hinuma, and Gamo were also examined.

Type locality: the estuary of the mouth of the Fujii-gawa River $\left(34^{\circ} 26^{\prime} \mathrm{N}, 133^{\circ} 15^{\prime} \mathrm{E}\right)$, pouring 
into Matsunaga Bay. This estuarine part is separated from the freshwater part by a concrete barrier, near which the type specimens were collected.

Male. Body (Fig. 2): Head with minute rostrum; lateral cephalic lobes subround, with notch, forming accessory lobes ventrally; eyes medium in size, slightly reniform. Dorsal surface of pleonal segments smooth, without medial dorsal teeth; urosomite 2 (Fig. 2-URS2) with dorsolateral spines. Epimeral plates 1-3 (Fig. 6E1-3) slightly produced ventroposteriorly, with minute setae along posterior margin. Epimeral plate 1 round posteriorly; epimeral plates 2 and 3 straight posteriorly, with some spines and setae along ventral margin.

Antenna 1 (Fig. 5-A1): Peduncular article 1 robust, with spines ventrally; article 2 elongate, longer than article 1 , with small spines along ventral margin and with groups of setae along dorsal and ventral margins; article 3 shortest, without spines. Main flagellum with ca. 30 articles (27 in holotype); accessory flagellum with up to 4 articles ( 3 in holotype).

Antenna 2 (Fig. 5-A2): Shorter than antenna 1; antennal gland cone pointed, with one small triangular projection at dorsal side of inner surface; peduncular article 3 with spines on inner surface; article 4 with spines on inner and dorsal surface, and with some short setae; article 5 slightly shorter than article 4, with some spines on inner surface, and with groups of setae. Flagellum densely setose, with ca. 15 articles (12 in holotype).

Mouth parts (Fig. 3): The same as in the four congeneric species of the previous report (Yamato, 1987), except the following points: third article of mandible palp setose only along medial margin, lacking setae along lateral margin; basal article of maxilla 1 palp lacking lateral setae.

Coxae 1-4 progressively developing longer; ventral margin smoothly subround, with minute setae. Coxa 4 excavate posterobasally. Coxae 5 and 6 with round

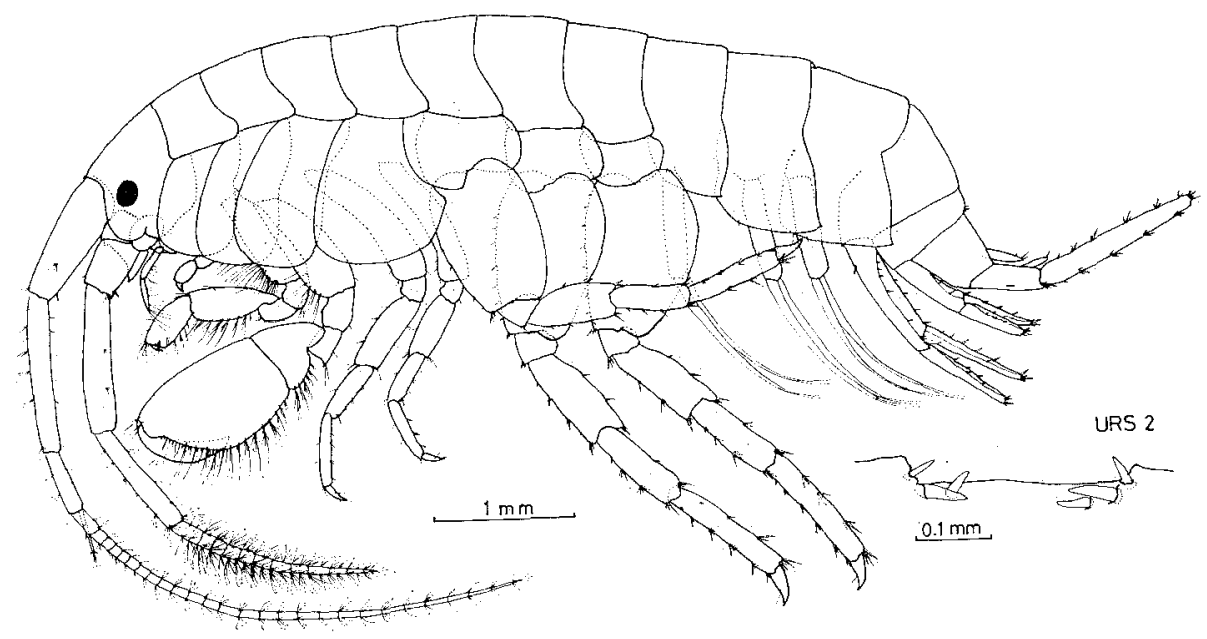

Fig. 2. Melita setiflagella n. sp. Male (1). 


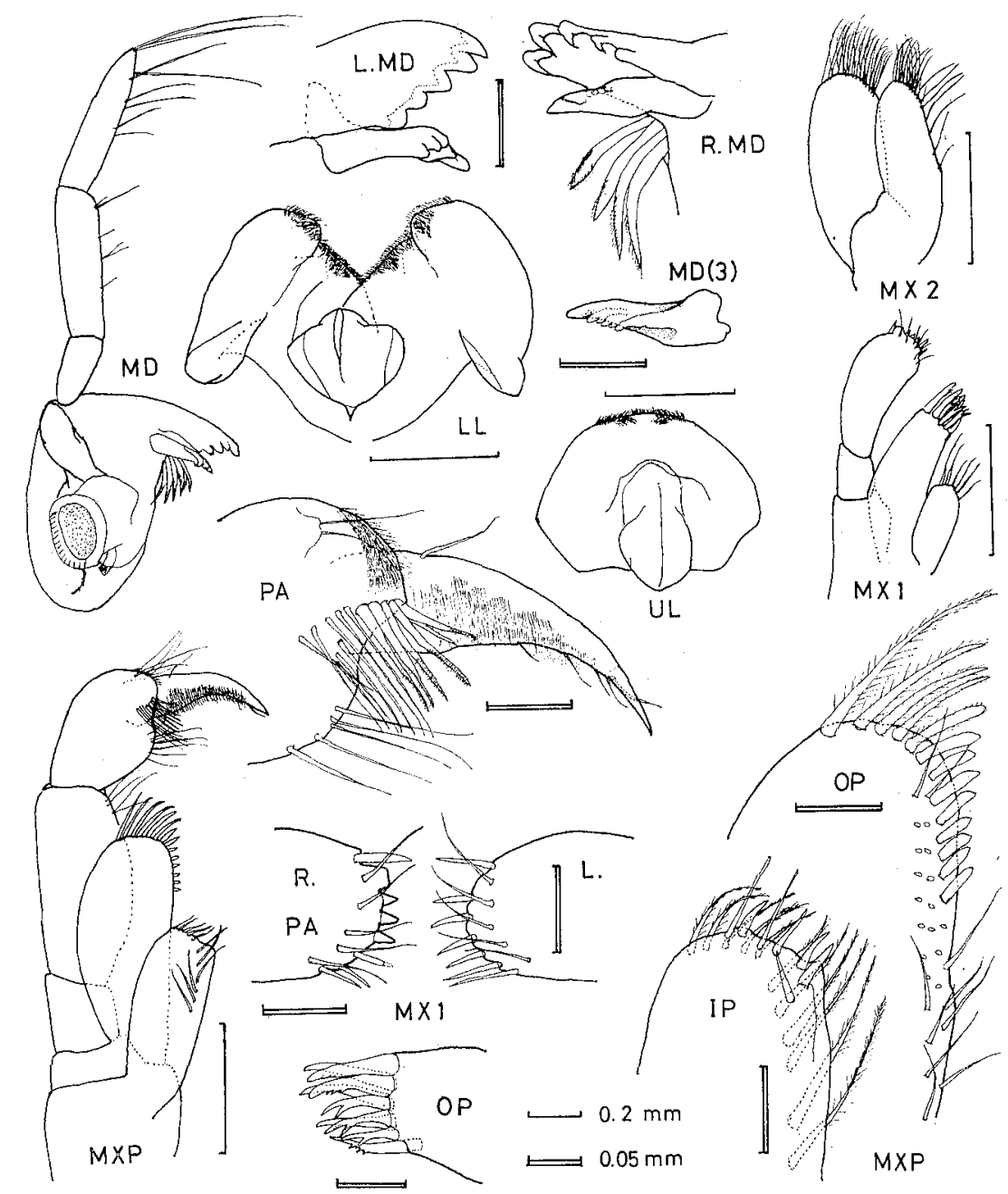

Fig. 3. Melita setiflagella n. sp. Male (1), male (3).

anterior lobe; coxa 7 unlobed. Coxal gills 2-6 round, simple; gill 2 slightly smaller than gill 3; gills 3-6 progressively decreasing in their size.

Gnathopod 1 (Fig. 4-G1): Article 2 with numerous long setae on distal half of anterior margin and some long setae on posterior margin; article 3 short, with setae at posterodistal margin; article 4 quadrate, with setae on posterodistal margin and dense setules on posteroproximal margin; article 5 long, setose on inner surface, with groups of a long simple seta and some pectinate setae along posterior margin, setulose on anterodistal part, which bears some pectinate spines. Article 6 excavated at basal part of palm on inner surface, with a protuberance at middle, slightly ridged obliquely at ventral subapical part; distal palmar margin short, convex, with bifurcated thin terminal spines, minute subterminal setae, and one small defining spine; posterior margin with groups of simple and pectinate setae. Dactyl short, 


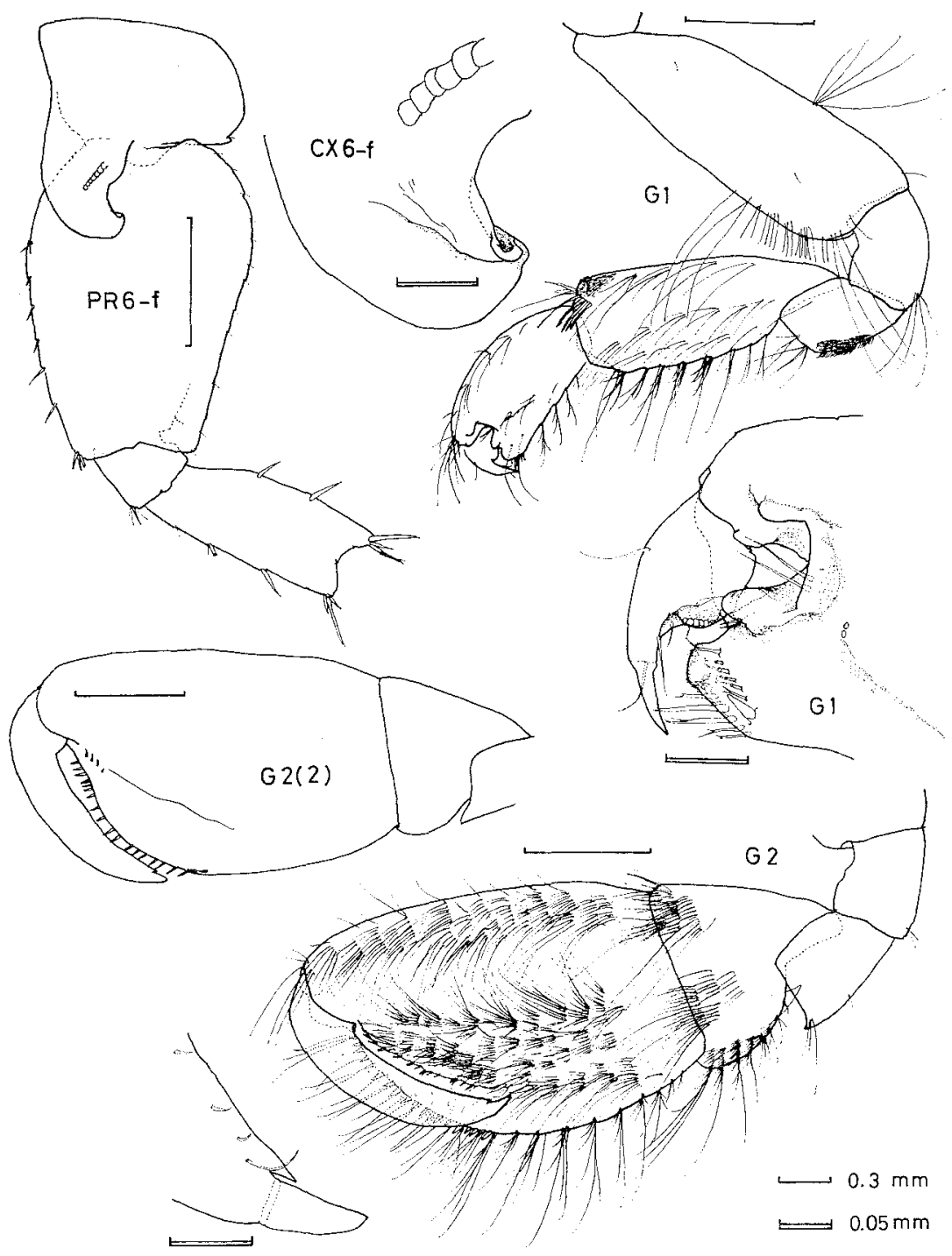

Fig. 4. Melita setiflagella n. sp. Male (1), male (2), female (1).

bulged basally, matching to the excavation of palm, nailed apically, with one seta on outer margin and several setae at basal part of nail.

Gnathopod 2 (Fig. 4-G2): Article 2 with many long setae along anterodistal margin and some long setae along posterior margin; article 3 short; article 4 short, posterodistally pointed; article 5 short, cup-shaped, with numerous setules along posterior margin and some rows of long setae on inner surface. Article 6 ovoid, slightly expanded posteriorly, (in male (2) (Fig. 4-G2 (2)) almost trapezcid); inner surface covered with numerous fine long setae, forming a slightly ridged channel lined with setae; outer surface with no armature; posterior margin with groups of 


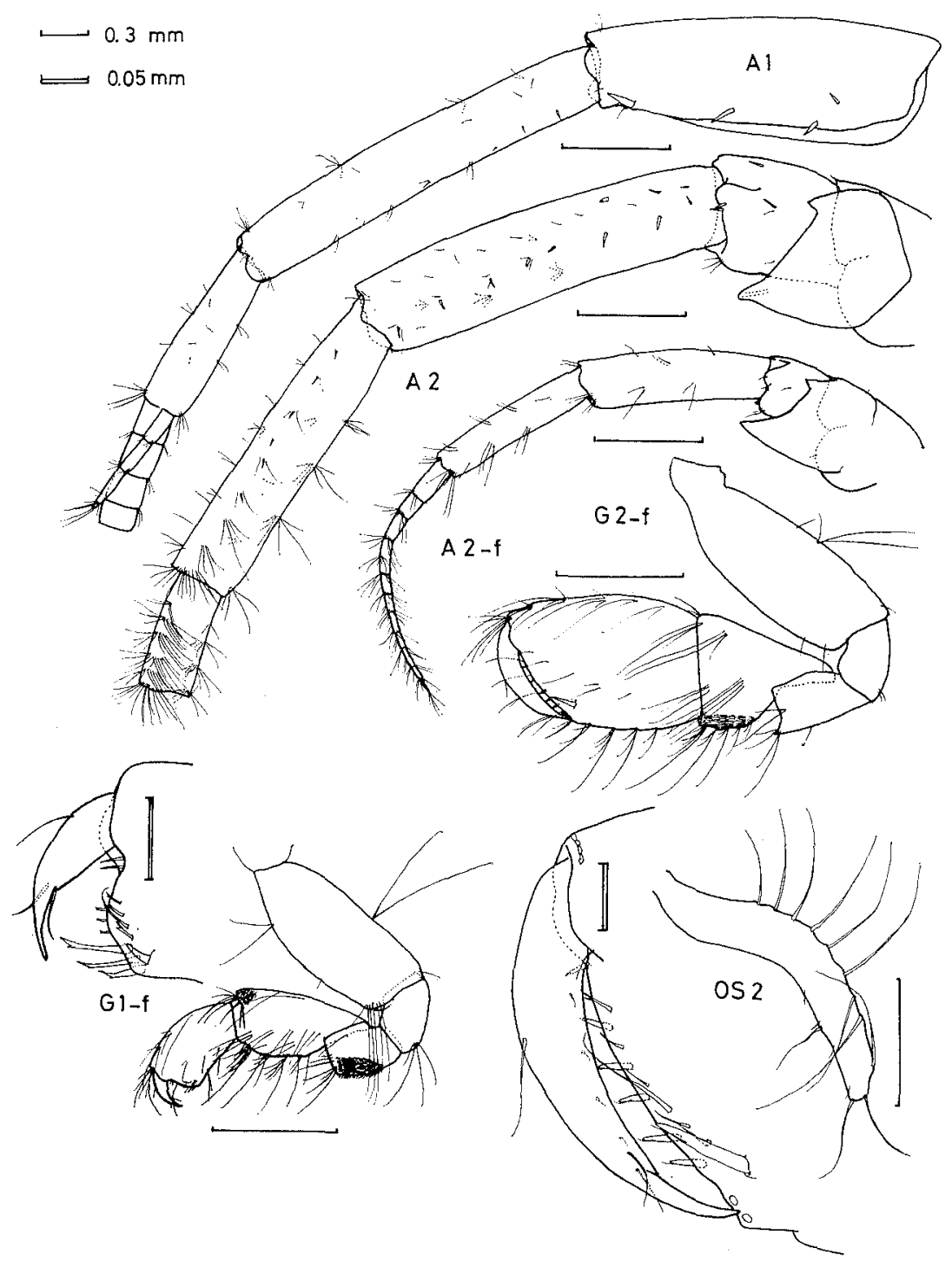

Fig. 5. Melita setiflagella n. sp. Male (1), female (1).

simple and pectinate setae; palmar margin with short spines and long setae. Dactyl stout, fitting into channel of article 6 , with a short seta on outer margin, and with indistinct obtuse nail, which bears a triangular process at basal part.

Pereopods 3 and 4 similar to each other; pereopod 4 slightly shorter than pereopod 3. Article 2 of pereopods 3-4 recurved, article 3 short; articles 4-6 linear; article 4 with some spines along anterior margin and short setae along posterior margin; articles 5-6 with short spines along posterior margin and short setae along anterior margin. Dactyl simple, without process, nailed apically, with a simple seta on inner margin, some minute subapical setae, and a plumose seta on outer margin. 


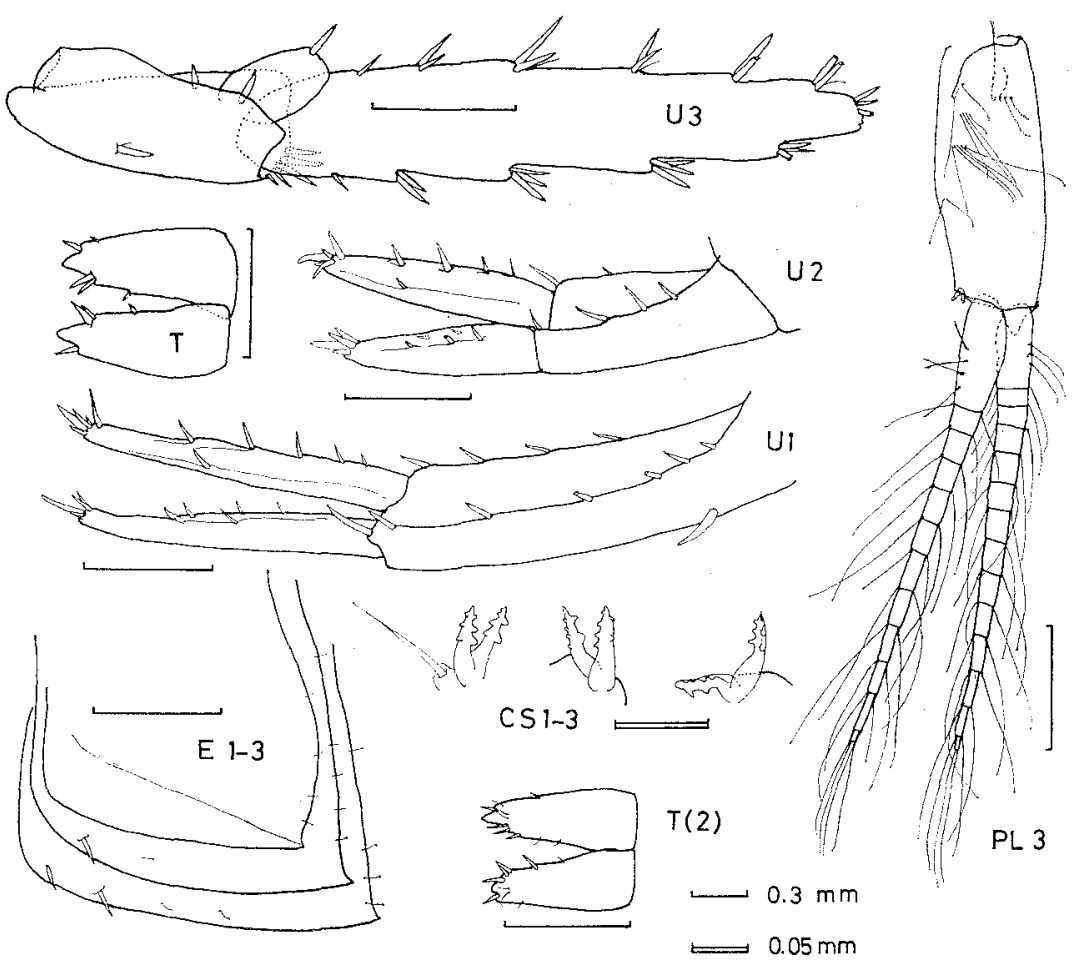

Fig. 6. Melita setiflagella n. sp. Male (1), male (2).

Pereopods 5-7 similar to each other; pereopod 5 shorter than pereopods 6 and 7. Article 2 of pereopods 5-7 slightly expanded posteriorly, slightly narrowed posterodistally, with very minute setae along posterior margin and with spines along anterior margin; article 3 short; articles 4-6 linear, with groups of spines marginally; article 5 subequal in length to article 4; dactyl as in pereopods 3 and 4 .

Pleopods 1-3 (Fig. 6-PL3): Pleopods 1 and 2 similar to each other; peduncle with two coupling spines and one or two short setae. Peduncle of pleopod 3 slightly shorter and more setose than those of pleopods 1 and 2, with two coupling spines. Basal article of each inner ramus with clothes-pin spines on medial margin.

Uropods 1 and 2 (Figs 6-U1, U2): Spinose along dorsal margins of peduncles as well as both rami and at apices of rami. Peduncle of uropod 1, with a ventrofacial spine and a long distolateral spine.

Uropod 3 (Fig. 6-U3): Peduncle much shorter than outer ramus, with spines on outer surface, on dorsal margin, and at apical part. Inner ramus short, scalelike, truncated apically, with one apical spine. Outer ramus elongate, uni-articulate, with groups of spines along both lateral and medial margins and at apex.

Telson (Figs 6-T, T(2)): Incised to base. Each lobe pointed apically, with groups of subapical spines and other spines along medial margin, (occasionally with spines along lateral margin). 
Female. Smaller than male. Antennae: Number of flagellar articles less than in male $(2,16$, and 8 articles in accessory, main flagellum of antenna 1, and flagellum of antenna 2, respectively, in allotype). Setation of antenna 2 flagellum (Fig. 5-A2f) weaker than male one.

Gnathopod 1 (Fig. 5-G1-f): Articles 2-4 as in male; article 5 shorter than in male. Article 6 quadrate, not excavated on inner surface. Dactyl not bulging basally.

Gnathopod 2 (Fig. 5-G2-f): Much smaller than in male; article 5 more elongate than in male. Article 6 ovoid, with sparse setae on inner surface; palmar margin oblique, with one row of short spines, one row of minute setae, and one strong spine at corner of palmar margin. Dactyl nailed, with a seta on anterior margin, subapical setae, and very minute setae on outer surface.

Anterior lobe of coxa 6 (Fig. 4-GX6-f) hooked, round apically, with a row of scale-like denticles.

Oostegites 2-5 (Fig. 5-OS2) narrow, with long setae.

Remarks. Antenna 2 of this new species bears setae densely. Within the genus Melita, two other species are known to have markedly setose antennae; i.e. Melita nitida Smith, 1873, from the north American coast of the Atlantic, and Melita elongata Sheridan, 1979, from the northwest Florida. Melita nitida was redescribed by Mills (1964) who designated the original specimens as the lectotype series. According to Mills' redescription, the peduncular article 5 and flagellum of antenna 2 of $M$. nitida are setose. In contrast this new species is setose only on the flagellum of antenna 2, but not on the peduncular article 5. This new species is also different from $M$. nitida in the presence of the notch at the inferior antennal corner of the head. Melita elongata differs from this new species in the characteristics of the setose peduncular articles 2, 3, and flagellum of antenna 1, and peduncular articles 4, 5, and flagellum of antenna 2.

In spite of the peculiar setation of antenna 2, this new species is similar to the four congeners previously reported from Japan by Yamato (1987), Melita rylovae Bulycheva, 1955, M. koreana Stephensen, 1944, M. nagatai Yamato, 1987, and $M$. bingoensis Yamato, 1987, in the general morphology of each appendage. This new species differs from the four species in the ovoid article 6 of male gnathopod 2, in the less developed posterodistal lobe of article 2 of pereopods $5-7$, in the shapes of articles 6 and 7 of male gnathopod 1, and in the female coxa 6 bearing a row of denticles.

\section{Melita shimizui (Uéno, 1940)}

(Figs 7-12)

(Japanese name: shimizumerita yokoebi, new)

Crangonyx shimizui Uéno, 1940a, pp. 74-78, figs 49-73; Uéno, 1940b, pp. 311-312, fig. 1.

Melita shimizui: Karaman, 1981, p. 44. 
Material examined. Male (1), $5.8 \mathrm{~mm}$, female (1), $3.6 \mathrm{~mm}$, female (2), $5.3 \mathrm{~mm}$, female (3), $4.6 \mathrm{~mm}$, (all females are ovigerous), 18 Apr. 1984, from Fujii-gawa; male (2), $6.5 \mathrm{~mm}$, female (4), $3.7 \mathrm{~mm}$, (ovigerous), 24 Mar. 1985, from Shioiri-hama; male (3), $5.0 \mathrm{~mm}$, 30 Dec. 1986, from Nakijin; male (4), $6.0 \mathrm{~mm}, 30$ Aug. 1984, from Sozu-gawa; male (5), $3.6 \mathrm{~mm}, 31$ Aug. 1986, from Nutagawa; male (6), $5.5 \mathrm{~mm}, 25 \mathrm{Apr}$. 1982, from Ohta-gawa. In addition to the above localities, a few specimens from Ochiai-gawa, 28 Apr. 1982, were also examined.

Male(1). Body (Fig. 7): Head with minute rostrum; lateral cephalic lobes subround, without notch; inferior antennal sinus almost quadrate. Eyes small, almost round. Dorsal surface of pleonal segments smooth, without medial dorsal teeth; urosomite 2 (Fig. 7-URS2) with two spines on each dorsolateral side. Epimeral plates 1-3 (Fig. 11-E1-3) produced ventroposteriorly; posterior margin convex, distinctly serrate and setose. Epimeral plates 2 and 3 with some spines and setae along ventral margin.

Antenna 1 (Fig. 8-A1): Peduncular article 1 robust, with some spines along ventral margin; article 2 elongate, longer than article 1, with setae sparsely; article 3 short, about half as long as article 2, with setae. Main flagellum with 19 articles; ventral side of each article with groups of medial and apical setae. Accessory flagellum consisting of two articles, the distal one minute.

Antenna 2 (Fig. 8-A2): Short, but longer than peduncle of antenna 1; antennal gland cone pointed, with one small triangular projection at dorsal side of inner surface; peduncular article 3 with spines at apex of round projection on inner surface, and at dorsodistal part; article 4 with one spine on inner surface and sparse setae; article 5 slightly shorter than article 4, with groups of setae. Flagellum short, slightly longer than peduncular article 5, with 7 articles.

Mouth parts (Fig. 8), coxae 1-7, and coxal gills are the same as in Melita setiflagella.

Gnathopod 1 (Fig. 9-G1): Article 2 with many long setae along anterodistal margin, some long setae along posterior margin, and fine setules on subapical part

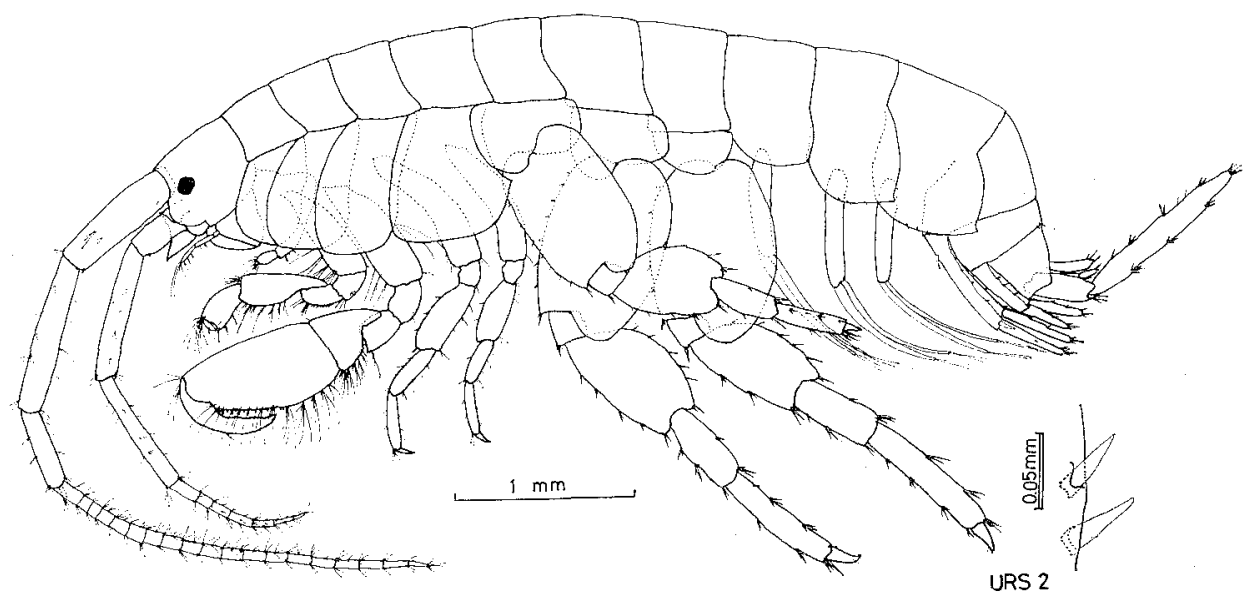

Fig. 7. Melita shimizui (Uéno). Male (1), Fujii-gawa. 


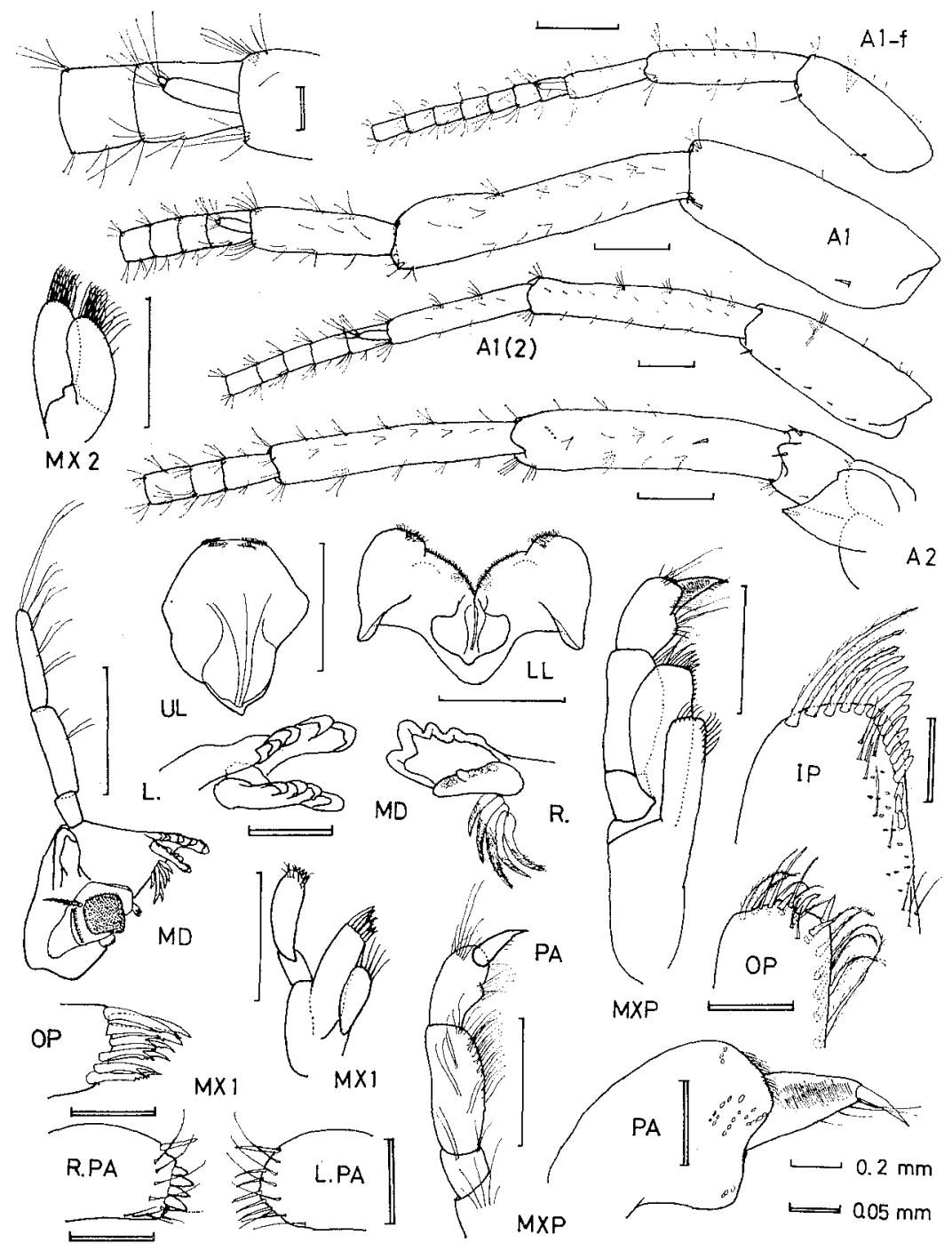

Fig. 8. Melita shimizui (Uéno). Male (1), Fujii-gawa; male (2), Shioiri-hama; female (1), Fujii-gawa.

of posterior margin; article 3 short, with setules and setae posteriorly; article 4 quadrate, setulose on posterior side; article 5 long, setose on inner surface, with groups of one long simple seta and some pectinate setae along posterior margin, setulose on anterodistal part which bears some pectinate spines. Article 6 excavated at basal part of palm on inner surface, with a distinct protuberance at the middle; distal palmar margin short, convex roundly, with two rows of bifurcated thin terminal spines and a defining spine; posterior and anterior margins with groups of setae. Dactyl short, bulged basally, with a tri-lobed process on inner margin, nailed apically, with one seta on outer margin and several setae at basal part of nail. 


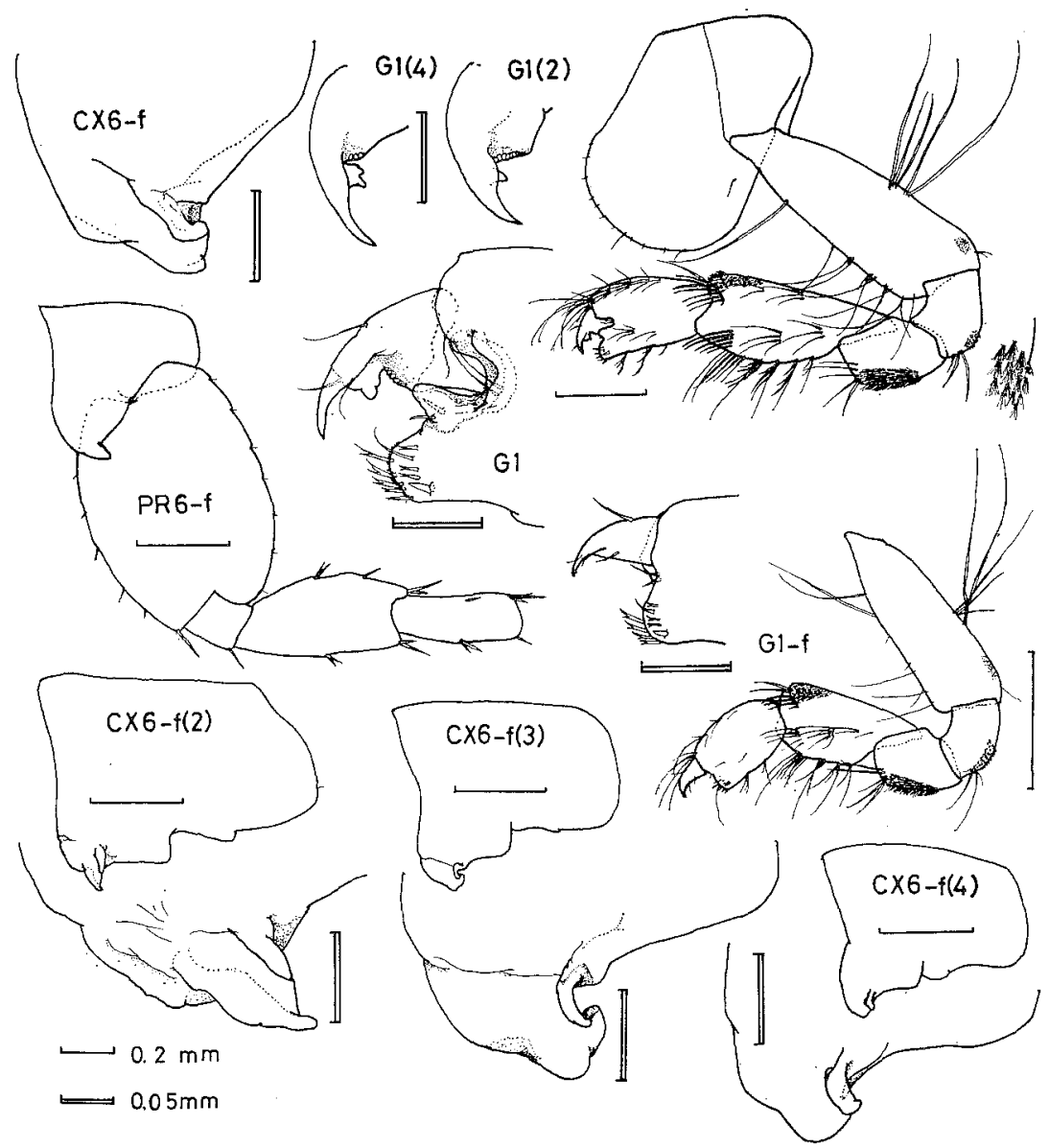

Fig. 9. Melita shimizui (Uéno). Male (1), Fujii-gawa; male (2), Shioiri-hama; male (4), Sozu-gawa; female (1-3), Fujii-gawa; female (4), Shioiri-hama.

Gnathopod 2 (Fig. 10-G2): Article 2 with long setae along anterior and posterior margins; article 3 short, setulose posteriorly; article 4 short, bluntly produced posterodistally article 5 short, cup-shaped, with numerous setules along posterior margin. Article 6 elongate, with sparse setae on inner surface, without armature on outer surface; posterior margin with groups of simple and pectinate setae; palmar margin serrate, slightly tuberculate, with long setae, two rows of spines, and a stout corner spine. Dactyl stout, overriding article 6, with one short seta on outer margin, and with indistinct obtuse nail, which bears a triangular process at basal part.

Pereopods 3 and 4 similar to each other; pereopod 4 slightly shorter than pereopod 3. Article 2 of pereopods 3-4 recurved, with long setae along posterior and anterior margins; article 3 short; articles 4-6 linear, with some short marginal setae. Dactyl simple, without process, nailed apically, with some simple setae subapically and a plumose seta on outer margin. 


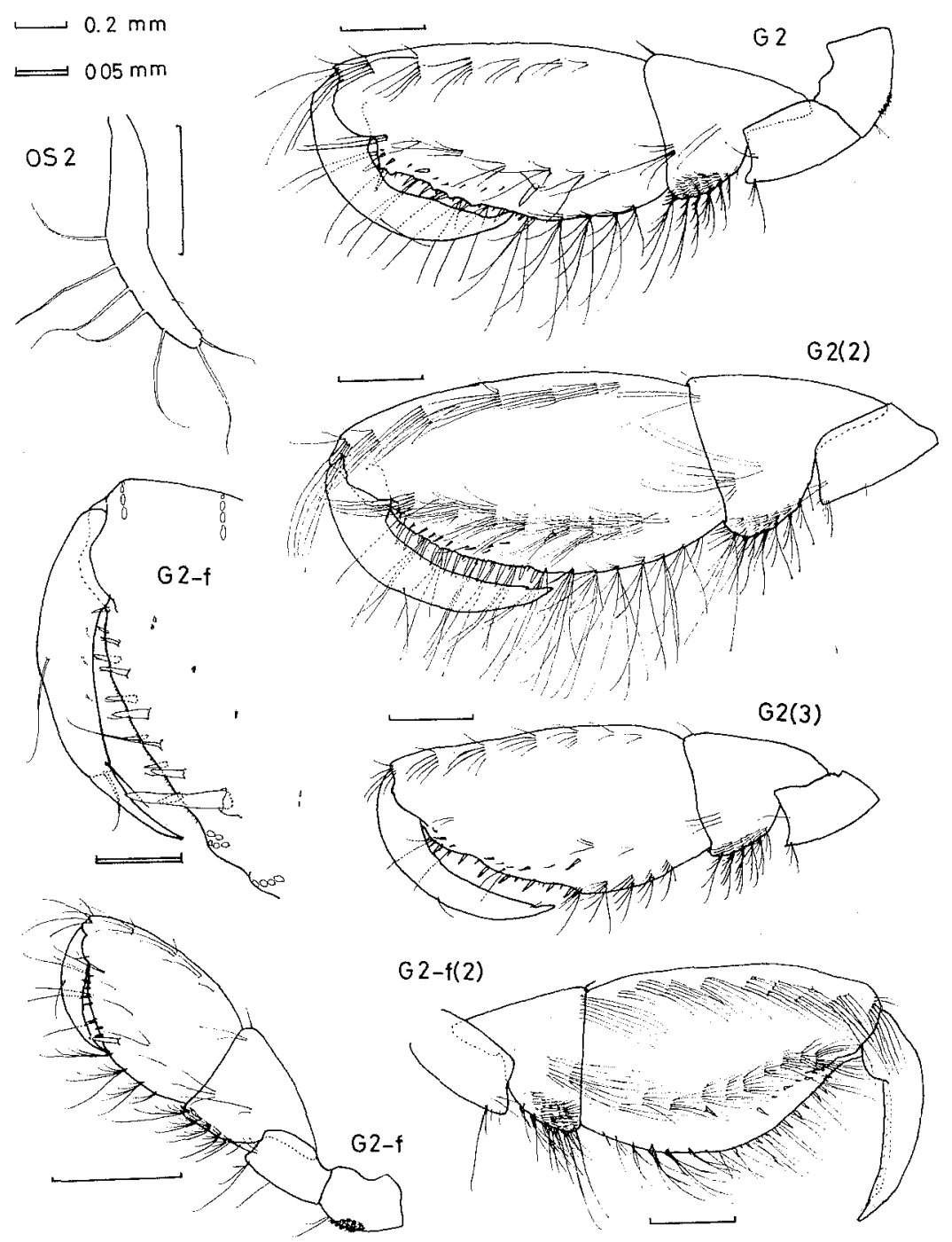

Fig. 10. Meliia shimizui (Uéno). Male (1), Fujii-gawa; male (2), Shioiri-hama; male (3), Nakijin; female (1-2), Fujii-gawa.

Pereopods 5-7 (Fig. 12-PR5) similar to each other; pereopod 5 shorter than pereopods 6 and 7 . Article 2 of pereopods 5-7 expanded posteriorly and well lobed posterodistally, with very minute setae along posterior margin and spines along anterior margin; article 3 short; article 4 robust; article 5 slightly shorter than article 4 ; article 6 linear, with some groups of spines marginally; dactyl as in pereopods 3 and 4 .

Pleopods 1-3 (Fig. 11-PL3): Pleopods 1 and 2 similar to each other; each peduncle with 2 coupling spines and a short seta on subapical part. Pleopod 3 slightly shorter than pleopods 1 and 2; peduncle with two coupling spines, and long 


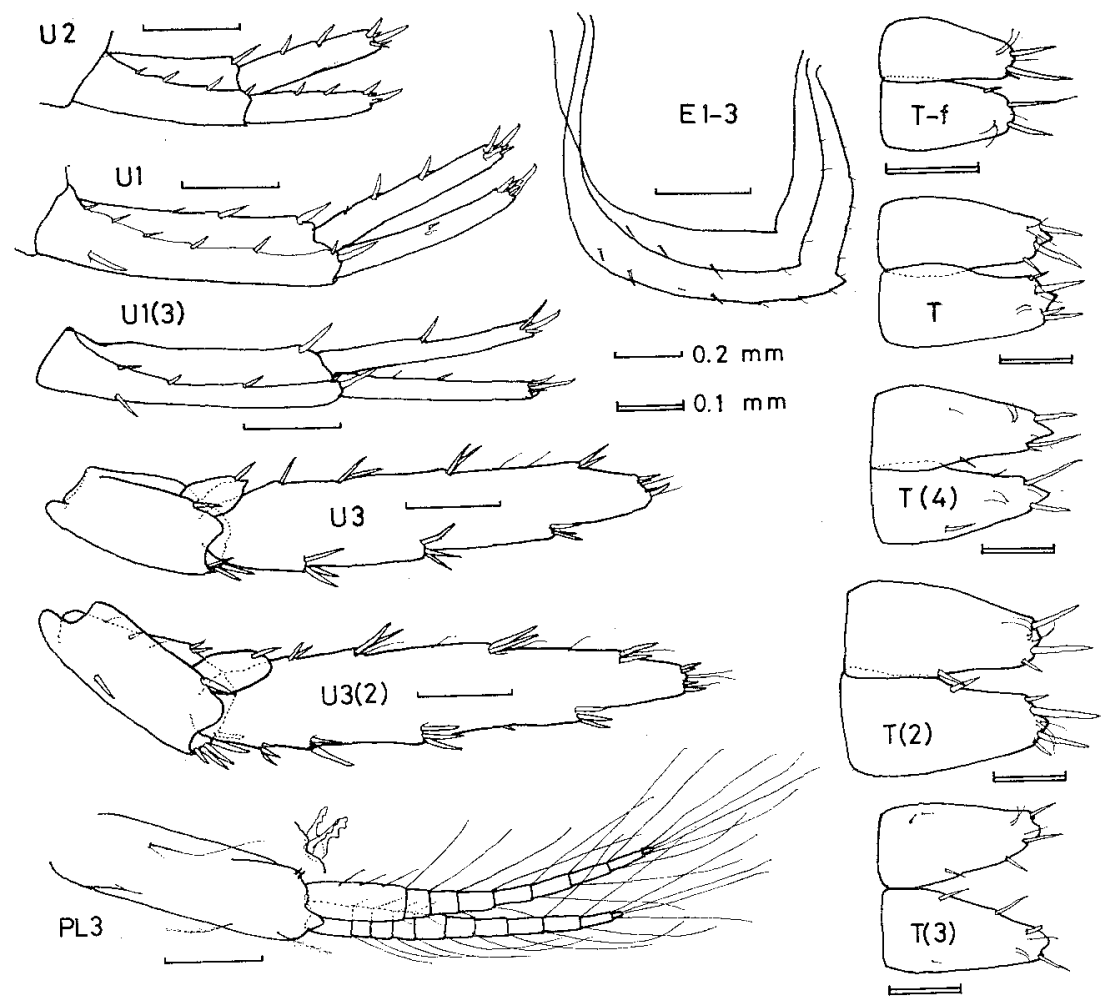

Fig. 11. Melita shimizui (Uéno). Male (1), Fujii-gawa; male (2), Shioiri-hama; male (3), Nakijin; male (4), Sozu-gawa; female (1), Fujii-gawa.

plumose setae along anterior margin. Basal article of each inner ramus, with clothespin spines on medial margin.

Uropods 1 and 2 (Figs 11-U1, U2): Spinose along dorsal margins of peduncles as well as both rami and at apices of rami. Peduncle of uropod 1, with one ventrofacial spine and one long distolateral spine.

Uropod 3 (Fig. 11-U3): Peduncle much shorter than outer ramus, with spines at dorsal margin and at ventroapical part, lacking spines on outer surface. Inner ramus short, scale-like, pointed apically, with one subapical spines. Outer ramus elongate, uni-articulate, with groups of spines along both lateral and medial margins and at apex.

Telson (Fig. 11-T): Incised to base. Each lobe pointed apically, with groups of subapical spines.

Variability of males. Some males were noticed to differ from male (1) in the following characters. Flagellar articles of antenna 1 are setose only on apical part of each and not setose on medial part (Fig. 8-Al (2)). Dactylar process of gnathopod 1 is bi-lobed (Fig. 9-G1 (4)) or simply triangular (Fig. 9-G1 (2)). Article 6 of gnathopod 2 is armed with dense setae (Fig. 10-G2 (2)) or sparse setae (Fig. 


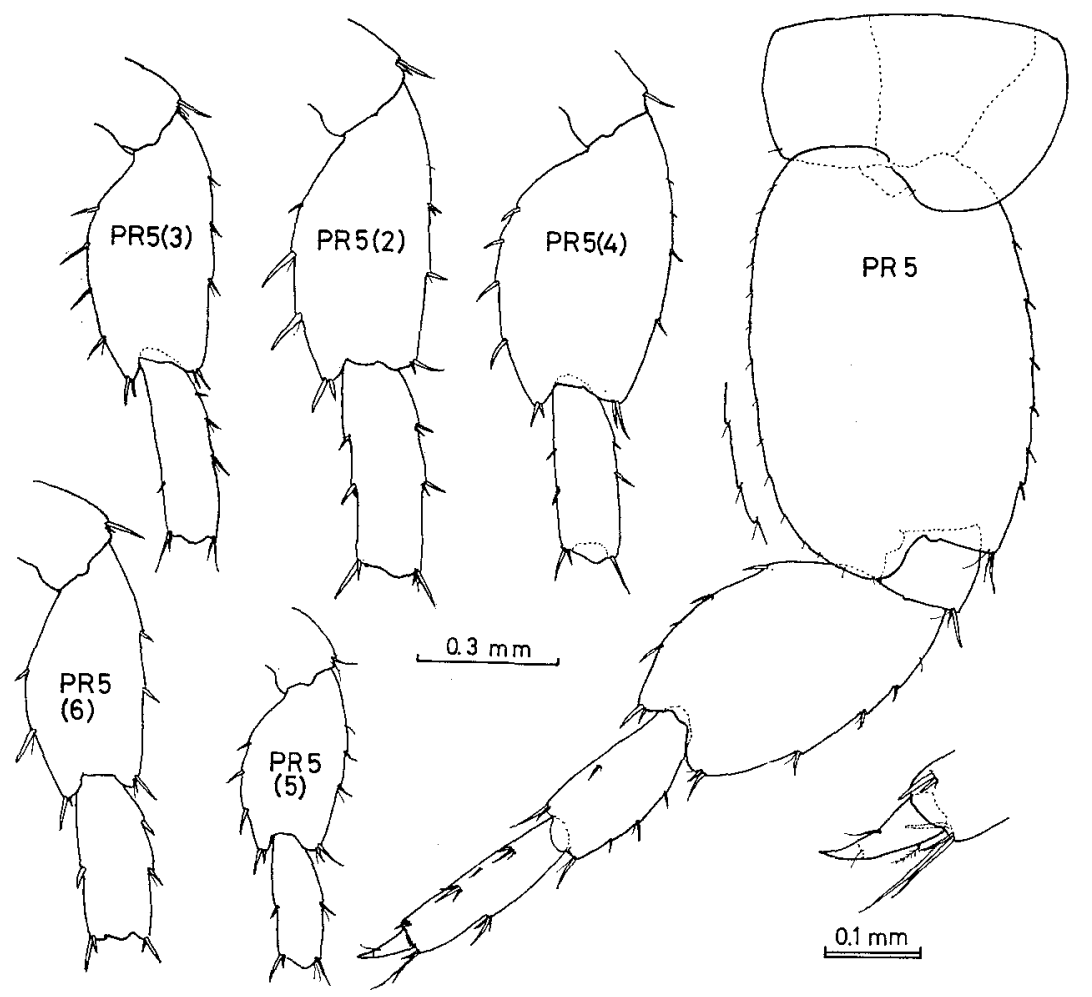

Fig. 12. Melita shimizui (Uéno), Articles 3-5 of pereopod 5. Male (1), Fujii-gawa; male (2), Shioiri-hama; male (3), Nakijin, male (4), Sozu-gawa; male (5), Nuta-gawa; male (6), Ohta-gawa.

10-G2 (3)). Article 4 of pereopods 5-7 is not robust (Figs 12-PR5 (2, 3, 6)). The spination of peduncle of uropod 1 is less developed (Fig. 11-U1 (3)). A spine is present on the outer surface of peduncle of uropod 3, and the inner ramus is round apically (Fig. 12-U3 (2)). The spination and the apical shape of telson also vary (Figs 11-T (2-4)).

Female. Smaller than male. Antennae: Number of flagellar articles and setation less than in male.

Gnathopod 1 (Fig. 9-G1-f): Articles 2-4 as in male; article 5 shorter than in male. Article 6 quadrate; palmar margin not excavated on inner surface. Dactyl not bulging basally, without process on inner margin.

Gnathopod 2 (Fig. 10-G2-f): Much smaller than in male; article 5 more elongate than in male. Article 6 ovoid; palmar margin oblique, with two rows of short spines and a strong defining spines. Dactyl wcakly nailed, with one seta on anterior margin, subapical setae, and very minute setae on outer surface.

Pereopods 5-7 (Fig. 9-PR6-f): Article 4 not extremely robust. Anterior lobe of coxa 6 (Fig. 9-CX6-f) hooked; apical part variously distorted, truncate or pointed (Figs 9-CX6 (2-4)); subapical part excavated triangularly. 
Oostegites 2-5 (Fig. 10-OS2) narrow, with long setae.

Remarks. All of the examined specimens agree with the original description of this species by Uéno (1940a), especially in the shape of lateral lobes of the head, 2-articulate accessory flagellum of antenna 1, the presence of dactylar process of male gnathopod 1, and the elongate article 6 and setulose article 3 of male gnathopod 2. As these characteristics are peculiar to this species between the known members of the genus Melita, I have identified the present material with it.

Despite this good concordance with the original description, some minor differences are noticed. One difference, which might give rise to another taxonomic problem of this species, is the degree of emargination of telson. In the present material, the telson is not different between the sexes. It is emarginated to the base irrespective of the sex. In contrast, Uéno (1940a) showed that the shape of the telson in his material was different between the sexes; the telson is emarginated to the base in the male, while it has an emargination as deep as three fourths the lengths in the female. This characteristic of the female telson might have caused him to erroneously assign his material to Crangonyx. The generic assignment of his material was strongly doubted by Holsinger (1977) in the review on crangonyctids, and later Karaman (1981) moved it to Melita. It is reasonable to assign this species to Melita, because most characters, including mouth parts, show similarities to the other Melita species, not Crangonyx species. I suppose that Uéno might fail to observe the accurate shape of the female telson.

The examined specimens of the male are divisible into at least three groups by the setation of the gnathopod 2 and the combination of other minor characters that were noted as variations in the above description. They would be here referred to as form 1, form 2, and form 3 tentatively; the characters to distinguish them are given in Table 1 together with notes on Uéno's material and their localities. It cannot be determined whether the original specimens from China fall in either one of these three groups or not, because the original description was mainly based upon the female specimens and was too poor with respect to these characters. The type specimens are not available, although $I$ have tried to trace them.

The "form 1" and "form 2" would not be geographic races because their localities are very close. Although there is a possibility that these three "forms" are actually separate species, it is, in my opinion, more likely that they are ecological varieties or ecophenotypes of the single species, M. shimizui. The type locality in China and the locality of "form 3" in Nakijin (Okinawa) are known to be freshwater habitats, and the water in the other localities is brackish. The salinity difference between their habitats might affect their morphology. However, it is obvious that a more detailed study of their morphology as well as their distribution pattern is necessary to determine the actual significance of these "forms".

This species is often found together with Melita setiflagella, but occurs in habitats strongly influenced by freshwater or in the center of the freshwater flows at low tide, 
Table 1. Three forms of Melita shimizui in Japan and their characteristics.

\begin{tabular}{|c|c|c|c|c|}
\hline Characters & form 1 & form 2 & form 3 & Uéno's specimens* \\
\hline Setae of Al flagellum & dense & sparse & sparse & sparse \\
\hline Dactylar process of $\mathrm{G} 1$ & $\begin{array}{l}\text { tri-lobed } \\
\quad \text { or bi-lobed }\end{array}$ & simple & simple & simple \\
\hline Setae on article 6 of $\mathrm{G} 2$ & sparse & dense & very sparse & very sparse?** \\
\hline Article 4 of PR 5-7 & robust & normal & normal & normal \\
\hline Spination of U1 & medium & medium & weak & weak?*** \\
\hline Peduncle spine of U3 & absent & present & present & $\operatorname{absent} * * * *$ \\
\hline Apex of U3 inner ramus & acute & round & acute & slightly acute \\
\hline Localities & $\begin{array}{l}\text { Fujii-gawa } \\
\text { Nuta-gawa } \\
\text { Sozu-gawa }\end{array}$ & $\begin{array}{l}\text { Ochiai-gawa } \\
\text { Ohta-gawa } \\
\text { Shioiri-hama }\end{array}$ & Nakijin & $\begin{array}{l}\text { Liaotung Peninsula } \\
\text { (China) }\end{array}$ \\
\hline
\end{tabular}

* Based on Uéno (1940a, b).

** The original description depicts the outer surface of male gnathopod 2, but its setae on article 6 , which are probably on inner surface, are depicted only on dorsal submargin.

*** In the original description the peduncle of uropod 1 bears only one basofacial and one distolateral spines, but the other peduncle spines might have been overlooked, because it is depicted together with urosomites.

**** In the original description uropod 3 is depicted with low magnification, so it is doubtful whether the spines are really absent.

while M. setiflagella occurs more seawards (Yamato, unpubl. data). This species is easily distinguishable from $M$. setiflagella in the smaller and slender body, the smaller eyes, and the presence of dactylar process of male gnathopod 1, the elongate form of male gnathopod 2, and the shape of hooked female coxa 6.

\section{Acknowledgment}

I would like to express my special thanks to the late Dr. Takaharu Hoshino of the Mukaishima Marine Biological Station, for critical reading of the manuscripts and encouraging me throughout this study. I thank Professor R. Katashima of Hiroshima University for reading the manuscript. I also wish to thank Dr. H. Morino of Ibaraki University and Mr. S. Ishimaru of Hokkaido University, for their critical reading of the manuscript and beneficial comments, and the staff of the Mukaishima Marine Biological Station for their encouragement and discussion. Thanks are also due to the following persons for making the materials available to me, Dr. C. Aryuthaka and Mr. S. Nishihama of Kyushu University, Mr. H. Ariyama of Osaka Prefectural Fisheries Experimental Station, and Dr. H. Morino. I am deeply grateful to Dr. J.L. Barnard of the Natural History Museum, Smithsonian Institution, for reading an earlier manuscript.

\section{References}

Holsinger, J.R. 1977. A review of the systematics of the holarctic amphipod family Crangonyctidae. Crustaceana, Suppl., 4: 244-281.

Karaman, G.S. 1981. Redescription of Melita planaterga Kunkel 1910 from Bermuda Islands with revision of genera Melita Leach and Abludomelita n. gen. (Contribution to the knowledge of the Amphipoda 119). Poljopriv. Sumarst., 27: 29-50.

Mills, E. 1964. Noteworthy Amphipoda (Crustacea) in the collection of the Yale Peabody Museum. Postilla, 79: 1-41. 
Sheridan, P.F. 1979. Three new special [sic] of Melita (Crustacea: Amphipoda), with notes on the amphipod fauna of the Apalachicola estuary of northwest Florida. Northwest Gulf Sci., 3: 66-73.

Uéno, M. 1940a. Some freshwater amphipods from Manchoukuo, Corea and Japan. Bull. Biogeogr. Soc. Japan, 10: 63-85.

. 1940b. Freshwater Amphipoda of Manchoukuo. Report of the Limnological Survey of Kwantung and Manchoukuo, Dairen: 311-322 (In Japanese).

Yamato, S. 1987. Four intertidal species of the genus Melita (Crustacea: Amphipoda) from Japanese waters, including descrpitions of two new species. Publ. Seto Mar. Biol. Lab., 32: 275-302. 